\title{
Consumers' attitudes towards functional dairy market in Croatia - a cross-sectional study
}

\author{
Ines Banjari ${ }^{1 *}$, Maja Domiter ${ }^{1}$, Tihana Ostrognjaj², \\ Ivana Petrović Vidić ${ }^{3}$
}

\author{
'Josip Juraj Strossmayer University of Osijek, Faculty of Food Technology, \\ Department of Food and Nutrition Research, F. Kuhača 20, HR-31000 Osijek, Croatia \\ ${ }^{2}$ EKO KOTOR d.o.o., J. Slavenskog 7, 40329 Kotoriba, Croatia \\ ${ }^{3}$ Dukat d.d., Velike Sredice 11, 43000 Bjelovar, Croatia \\ *Corresponding author: ibanjari@ptfos.hr
}

\section{Abstract}

Modern consumers ask for foods that have beneficial effects beyond the traditionally known nutritional role. This is the core definition of functional foods, however, many consumers are confused with what functionality represents. Milk and dairy products stand out as the largest segment of functional foods. Given the diversity of Croatia's functional dairy market, the aim of this study was to conduct market analysis and to analyse whether consumers' attitudes towards functional foods in general, and specifically functional dairy products, changed throughout years (by comparing year 2011/12 to 2019). Market analysis was done according to the standardized methodology while for consumer's attitudes an online, study-specific questionnaire was used. The same questionnaire was used for both study years. Total of 231 participants in 2011/12 and 221 in 2019 completed the questionnaire. In comparison to $2011 / 12$, statistically less people are buying functional foods (44.3 \% in 2019 vs $63.5 \%$ in 2011/12, $p=0.026$ ) but the awareness improved over time, especially regarding probiotics. Within eight years, two new growing categories of functional dairy were identified; yoghurt with chia seeds and high-protein products, while the range of lactose-free products bloomed. Cross-sectional analysis showed that the only consistent independent indicator of consumer's decision to buy a functional over a regular product is the self-care for health, which increases the likelihood by $50.2 \%$. Unlike eight years ago, pre-existence of a medical condition increases the likelihood to buy a lactose-free product (by $47.4 \%$ ), regardless of what the medical condition is. Despite some positive shifts observed, general awareness of what functionality represents and what is the intended purpose of a product is fragmentary. Our findings support the need for stronger, specifically targeted evidence-based communication towards the consumers.

Key words: functional dairy, market analysis, consumer attitudes, consumer awareness, health benefits 


\section{Introduction}

Functional food (FF) is food which besides its basic energy and nutritional value, has a positive effect on one or more target body functions, improves overall health and well-being, reduces the risk of specific diseases, or minimizes the effects of other health concerns (Kapsak et al., 2011). The International Food Information Council (IFIC) defines functional food as food which provides greater health benefits than common food (Čalić et al., 2011). In other words, FF has to possess physiologic or psychologic effect beyond the traditional nutritional effect (Roberfroid, 2000). A total of five approaches are used in FF production (Roberfroid, 2000), but FF with added components (eg. margarine fortified with omega-3 fatty acids, under the Regulation of Nutrient Enriched Food (MZSS, 2008) and FF with reduced/eliminated component (eg. low-fat milk) make up the majority of the market (Ozen et al. 2012). Out of all FF, functional dairy products are conquering the market worldwide (Statista, 2020a; Transparency Market Research, 2016; Granato et al., 2010), from probiotic, prebiotic, and symbiotic products, low cholesterol fresh milk, omega-3-milk, low lactose, and lactose free products and milk products that can control or manage hypertension and immune functions (Shiby and Mishra, 2013). Especially strong is the European market (IPA Europe, 2020; Transparency Market Research, 2016; Muminović and Pavlović, 2012; Granato et al., 2010), while Croatia together with the Netherlands, Scandinavian countires, Switzerland, and Estonia are the main European markets of dairy probiotics (Vergari et al, 2010).

Increased demand for sustainable production and environment preservation (IEEP, 2020), along with ageing society, are shaping up the dairy market. Altogether, the increased health consciousness drives the overall demand for probiotics across Europe (IPA Europe, 2020). Probiotics are the most studied functional dairy products with extensively proven effectiveness in the prevention of gastrointestinal disorders, normalization of the gut microbiota, lactose intolerance and blood cholesterol levels (Martins et al., 2018).

The aim was to conduct the analysis of functional dairy market in Croatia and accordingly to test consumers' attitudes towards the identified products. Additionally, changes in consumers' attitudes towards FF in general and functional dairy products were compared between 2011/12 and 2019.

\section{Materials and methods}

\section{Market analysis}

Market analysis was done according to the standardized methodology by Dunford et al. (2012) in six retail chains (Konzum, Kaufland, Plodine, Spar, Lidl and Bio\&Bio) during March 2019 in the city of Varaždin. Product information and nutrition labels for each functional dairy product (milk, yoghurt and cheese) available in the selected large retail-chains were used to create the database. This database was used to prepare the second stage of the research, adapt an existing questionnaire to fit current market state. (Authors' note: The database can be found in Domiter, 2019 or requested).

\section{Survey of consumers' attitudes towards functional foods}

A cross-sectional study assessing consumers' attitudes towards FF was conducted in 2011/12 and 2019 by using the modified questionnaire developed by Landström et al. (2007). Modification refers to the addition of questions about new products identified on the market (based on the market analysis, eg. yoghurt with chia seeds). Publically available service (Google Forms) was used to prepare and distribute the questionnaire, to ensure anonymity and personal data protection.

The first part of the questionnaire covered basic demographic and socioeconomic characteristics of respondents and their current health status. Respondents were asked to self-report current body weight (in $\mathrm{kg}$ ) and height (in $\mathrm{cm}$ ) which were used to calculate Body Mass Index (BMI; weight in kilograms derived by height in metres squared). According to the calculated BMl they were categorized as underweight, normal weight, overweight or obese (WHO, 2006). The second part examines the knowledge of the definition of FF, frequency of purchase and/or consumption of functional products, 
by category and/or type of product. The third part consists of questions about attitudes towards FF, knowledge of their presence on the market, reasons for purchasing and expectations of functional products. Since the questionnaire covered a range of topics related to FF, the following were taken for this analysis: year of survey, age (in years), sex, $\mathrm{BMl}\left(\mathrm{kg} / \mathrm{m}^{2}\right.$ and category), residence, self-care for health, pre-existing medical condition, definition of FF, frequency of purchase and/or consumption of functional products (in general, probiotics, lactose-free products, yoghurt with cereals, products with reduced fat content), source of information, reasons behind purchase, the importance of price, expectations and improvements noticed. (Authors' note: The questionnaire is available upon request).

The survey was conducted between December 2011 and February 2012 (Year 1) and again between April and May 2019 (Year 2). Both times, the recruitment was done by publishing the basic research information along with the survey questionnaire link via social networks. The aim was

TABLE 1. Participants' general characteristics for both survey years, Year 1 (2011/12) and Year 2 (2019)

\begin{tabular}{|c|c|c|c|c|c|}
\hline & & \multicolumn{2}{|c|}{ Year 1} & \multicolumn{2}{|c|}{ Year 2} \\
\hline & & $\mathrm{n}$ & $\%$ & $\mathrm{n}$ & $\%$ \\
\hline \multirow[t]{2}{*}{ Gender } & Men & 85 & 36.8 & 34 & 15.4 \\
\hline & Women & 146 & 63.2 & 187 & 84.6 \\
\hline \multirow{7}{*}{$\begin{array}{l}\text { Age range } \\
\text { (years) }\end{array}$} & $18-24$ & 57 & 24.7 & 93 & 42.1 \\
\hline & $25-34$ & 78 & 33.8 & 62 & 28.1 \\
\hline & $35-44$ & 38 & 16.5 & 32 & 14.5 \\
\hline & $45-54$ & 32 & 13.9 & 17 & 7.7 \\
\hline & $55-64$ & 25 & 10.8 & 14 & 6.3 \\
\hline & $65-74$ & 1 & 0.4 & 1 & 0.5 \\
\hline & $\geq 75$ & 0 & 0.0 & 2 & 0.9 \\
\hline \multirow{4}{*}{$\begin{array}{l}\text { BMI } \\
\text { category }\end{array}$} & Underweight & 5 & 2.2 & 6 & 2.8 \\
\hline & $\begin{array}{l}\text { Normal } \\
\text { weight }\end{array}$ & 131 & 56.7 & 153 & 70.5 \\
\hline & Overweight & 78 & 33.8 & 46 & 21.2 \\
\hline & Obese & 17 & 7.4 & 12 & 5.5 \\
\hline \multirow[t]{2}{*}{ Residence } & Urban area & 104 & 45.2 & 176 & 83.0 \\
\hline & Rural area & 126 & 54.8 & 36 & 17.0 \\
\hline
\end{tabular}

to collect answers for a minimum of 150 people aged 18 and over, of both sexes, regardless of their health status and place of residence. Total of 231 responses (median age 31 years) were collected in Year 1 and 221 in Year 2 (median age 25 years). General participants' characteristics are shown in Table 1.

\section{Statistical analysis}

Software Statistica 13.3 (StatSoft, Tulsa, OK, USA) was used for all calculations. Normality of data distribution was tested by the nonparametric Kolmogorov-Smirnov test for the comparison of medians and arithmetic mean, and histograms plotting. The results are presented as median and interquartile range, and as absolute and relative frequencies. Chi-square test was used to compare categorical data, while Spearman's test was used for correlation ranks. Logistic regression was used to test changes in consumers' attitudes over time. To calculate odds ratios for time-related change as binary variables in relation to one or more independent variables related to consumers' attitudes univariate and multiple logistic regression were used, respectively. For the latter, we retained significant independent factors from univariate logistic regression. The accepted probability of alpha error was 0.05 .

\section{Results and discussion}

\section{Market analysis}

Croatia's market of milk and dairy is stable; the average annual spending per household on milk, cheese and eggs between years 2017 (CBS, 2019) and 2009 (CBS, 2011) have not changed much (15.5\% vs $15.8 \%$ of the total household spending, respectively). According to the latest household survey (CBS, 2016) $66.2 \mathrm{~L}$ of milk and $17.4 \mathrm{~kg}$ of other dairy (excluding cheese) were consumed on a household level in year 2014. On the other hand, in 2010 (CBS, 2012) $77.4 \mathrm{~L}$ of milk and $16.4 \mathrm{~kg}$ of other dairy (excluding cheese) were consumed per household. This clear shift in consumers' preference can be explained with a wider product range, influence of globalisation (Huynen et al., 2005) and 


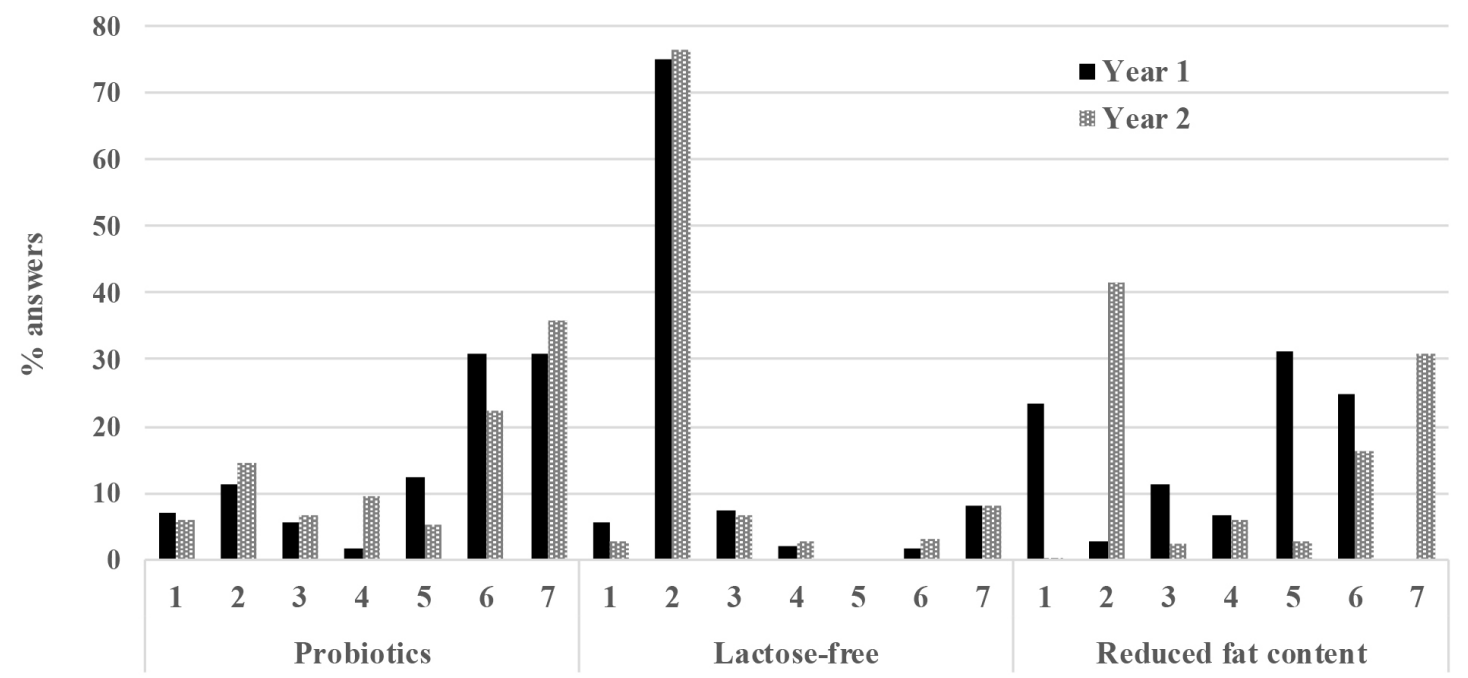

1 - I don't know what are those products; 2 - Never; 3 - Tried once but don't like them; 4 - Every day; 5 - 5 times a week; 6 - 2 to 3 times a week; 7 - 2 to 3 times a month

FIGURE 1. Participants' answers regarding the consumption of probiotics, lactose-fee and products with reduced fat content in Year $1(2011 / 12)$ and Year 2 (2019)

promotion of healthy lifestyle through media, especially health benefits of fermented dairy products (Phillipov, 2016). Certainly, the increased number of individuals suffering from specific medical condition such as lactose intolerance, chronic gastritis, some autoimmune conditions, thyroid diseases play an important role in the observed shift (Statista, 2020b), and we can expect these shifts to deepen further.

The total of 243 products fit within the functional dairy category and were included into the database; 24 milks (reduced fat content, added vitamins/minerals or omega-3 fatty acids, fermented, lactose free and goat milk) and 219 fermented dairy products. We identified two new categories which were not available on the market in Year 1; chia seed yoghurt and high-protein products, while the number of lactose-free products expanded to all groups of milk and dairy products (milk, yoghurt, sour cream, milk or cheese spreads, soft and hard cheese). Chia seed yoghurt is consumed by $30.3 \%$ of consumers and high-protein dairy products by $13.6 \%$ (Domiter, 2019).

Nutritionally, energy value varies between 17 kcal for whey to $367 \mathrm{kcal}$ for lactose-free hard cheese per $100 \mathrm{~g}$ of product. Fat content ranges from < $0.1 \mathrm{~g}$ (two yoghurts) to $10 \mathrm{~g}$ in Greek style yoghurt, while cheese spreads and cheese reach 26 g per $100 \mathrm{~g}$ of product. Protein content varies between $0.06 \mathrm{~g}$ (in whey) to $33 \mathrm{~g}$ per $100 \mathrm{~g}$ of product (in hard cheese). Dietary fibers are reported on 55 products (all yoghurts) and ranges from 0.02 to 1.9 g. Calcium content is given only on 61 products, while 23 products have vitamin D content. Five products had $<0.01 \mathrm{~g}$ of lactose, while additional $21 \mathrm{had}<0.1 \mathrm{~g}$ of lactose. According to the EU legislation, products labelled as "lactose-fee" must contain $\leq 10 \mathrm{mg}$ of lactose per $100 \mathrm{kcal}$ (FDF, 2015). Though small, this is the first database containing valuable nutrition information of functional dairy products available on Croatia's market.

\section{Cross-sectional analysis of consumers' attitudes}

In comparison to Year 1 when $63.5 \%$ of participants said they were buying FF, statistically less people in Year 2 (44.3\%) said they were buying FF $(p=0.026)$. It is important to note that respondents were not given the definition of FF prior the survey. This shift does not necessarily mean that less people consume FF, which is supported by the results shown in Figure 1. In comparison to Year 1, fewer people in Year 2 said that they were not familiar with probiotics (5.9\% vs $7.0 \%$ ), lactose-free products ( $2.7 \%$ vs $5.6 \%$ ) or products with reduced 
TABLE 2. Participants' answers regarding the definition of functional foods, source of information and the reasons for choosing and buying a functional product over a regular one between survey conducted in Year 1 (2011/12) and Year 2 (2019)

\begin{tabular}{|c|c|c|c|c|}
\hline & \multirow[t]{2}{*}{ Answer } & \multirow{2}{*}{$\begin{array}{l}\text { Year } 1 \\
\%\end{array}$} & \multirow{2}{*}{$\begin{array}{l}\text { Year } 2 \\
\%\end{array}$} & \multirow[t]{2}{*}{$\mathrm{p}$} \\
\hline & & & & \\
\hline \multirow{6}{*}{$\begin{array}{l}\text { How would you define what } \\
\text { functional foods are? }\end{array}$} & Products with positive effect on health & 51.9 & 26.9 & $<0.0001^{*}$ \\
\hline & Products that prevent diseases & 17.9 & 39.9 & $<0.0001^{*}$ \\
\hline & Products which will lower blood cholesterol & 10.9 & 13.6 & 0.296 \\
\hline & Ecologically produced (organic) & 7.1 & 12.7 & $0.017^{*}$ \\
\hline & Products only available in stores selling healthy foods & 6.1 & 3.4 & 0.111 \\
\hline & Other & 6.1 & 3.4 & 0.111 \\
\hline \multirow{6}{*}{$\begin{array}{l}\text { The source of information } \\
\text { about functional foods }\end{array}$} & TV commercials & 26.7 & 13.0 & $0.001^{*}$ \\
\hline & Newspapers/Magazine & 9.6 & 14.3 & 0.096 \\
\hline & Internet & 27.0 & 34.6 & 0.056 \\
\hline & By reading product's declaration & 12.2 & 14.7 & 0.396 \\
\hline & Recommendation from a friend & 12.5 & 10.0 & 0.350 \\
\hline & Other & 11.9 & 13.4 & 0.597 \\
\hline \multirow{4}{*}{$\begin{array}{l}\text { The reason for choosing and } \\
\text { buying a functional products } \\
\text { over a regular one }\end{array}$} & Curiosity & 28.3 & 33.2 & 0.220 \\
\hline & Wish to improve health & 27.9 & 26.4 & 0.689 \\
\hline & I am health conscious & 33.8 & 30.6 & 0.436 \\
\hline & Regularly buying healthy foods & 10.0 & 9.8 & 0.929 \\
\hline
\end{tabular}

Chi-square test; *significant at $p<0.05$

fat content ( $0.5 \%$ vs $23.5 \%, p<0.001)$. Out of all functional dairy products covered in the questionnaire, the least liked and consumed was yoghurt with cereals (packed together). In Year 1, around the time when this product first appeared on the market, $35.3 \%$ said they never tried the product, $11.2 \%$ tried but did not like it, while in Year 2 even $74.7 \%$ said they never tried the product (the results are not shown).

Additionally, the observed shift during a time span of eight years implies that people became more aware of what FF are, and what beneficial effects they desire from FF, as shown in Table 2 (Authors' note: Participants could choose more answers per question asked). In comparison to Year 1, more people attributed the preventing effect to FF $(p<0.0001)$, rather than generally describing them as products with a "positive effect on health" $(p<0.0001)$. Interestingly, more people associated FF with organic products $(p=0.017)$ which was in line with an earlier study conducted on a sample of 555 German consumers, clearly showing the overlap between FF and organic products (Goetzke et al., 2014). In other words, "what is good for the planet is good for your health" is a moto of modern consumers, especially the younger ones. Though the environmentally sustainable trend is in a slight decline in the US, organic products are still highly desired according to the latest Food and Health Survey conducted in 2019 (IFIC, 2019). Our results showed that the message communicated from the producer's side is clearer, but more is to be done on the consumer awareness side.

According to Siró et al. (2008) the term FF is often unfamiliar to the European consumers, and this has not changed significantly (Annunziata and Vecchio, 2011). Communicating the health effects reliably to the final consumer is manufacturer's responsibility and should be their priority 
(Annunziata and Vecchio, 2011). However, regulatory aspects in the EU might be the major obstacle, especially when health claims are considered. Regulation on the Health and Nutrition Claims started to apply on July 1, 2007 (EC, 2006) and since then, very few health claims were approved. Even though it's initial purpose was to protect consumers from false advertising, it is a major set-back to the manufacturers because of the slow, endless procedure discouraging them to proceed with the application. This should not be disregarded when discussing consumers' confusion over FF.

Consumers rely on a number of sources to obtain pre-purchase information, but when overloaded with information they tend to become selective regarding how much and which information they access (Akalamkam and Mitra, 2017). While traditional sources (word of mouth, ie. recommendation from a friend) are considered to be the most trusted source of information globally, Internet is taking the lead, especially among younger consumers (IFIC, 2018). Our results were in line with the aforementioned findings. Internet remained the main source of information, but in comparison to Year 1, significantly less people in Year 2 relied on TV commercials $(p=0.0001)$ or word of mouth (10.0 \% vs $12.5 \%$ ) (Table 2). Finland's consumers consider public bodies as the most trustworthy source, followed by newspapers, retailers and manufacturers (Siró et al., 2008). In the US, despite primarily turning to the Internet for information, consumers put their trust into health experts (IFIC, 2018). It is obvious that the Internet is taking the primary role when it comes to consumer information (Dowling, 2016). This emphasizes the need for tighter regulations to avoid distribution of misleading and false information (Southey, 2019). Lower familiarity with the Internet will lead to a greater use of traditional sources (Akalamkam and Mitra, 2017), meaning that a different strategy should be used for each targeted population group (ie. TV commercials for the elderly). Product's declaration is a valuable source of information, and considered to be a valuable public health measure to improve consumers' awareness on nutritional aspects of their diet, even among people with limited knowledge about nutrition (Viola et al., 2016). However, one previous study conducted on a representative sample of 1,011 Croatian subjects over 15 years of age found that $19 \%$ of subjects always read nutrition label, additional $15 \%$ sometimes, while 25 $\%$ read nutrition label rarely and $36 \%$ never (Ranilović and Colić Barić, 2011). Considering these results, it is of no surprise that only a small share of consumer rely on product's declaration as a source of information about FF is not surprising ( $14.7 \%$ in 2019 vs $12.2 \%$ in 2011/12; Table 2). As reported by Domiter (2019) most people read declaration only on selected products (30.1\%), $24.2 \%$ understand the declaration completely, font used is too small for $9.6 \%$ and confuses $2.1 \%$ of participants. Larger font on the label represents a barrier for older consumers (Ranilović and Colić Barić, 2011) but also for "label non-users" (Ranilović and Colić Barić, 2013). Importantly, for the majority of "label non-users" (37.6\%) health problems represent the main motive to start reading nutrition label (Ranilović and Colić Barić, 2013). These findings could enable tailoring of specific strategies to improve consumer's awareness regarding product's functional properties.

The reasons why people buy FF are very diverse, yet healthiness and well-being are something all have in common (Hosni and Periklis, 2017; Ozan et al., 2012) and therefore, a consumer will choose a functional over a regular product (Temesi et al., 2019; Jasiulewicz and Lemanowicz, 2016). In addition, experience with a medical condition increases the likelihood of accepting FF (Siró et al., 2008). Currently, the most desired health benefits consumers (as indicated by more than $40 \%$ of respondents) seek from foods are weight loss/weight management, energy, digestive health, heart/cardiovascular health, muscle health/strength, brain function and bone health (IFIC, 2019). These interests vary with age of a consumer - younger preferring weight management and energy, and older consumers seeking cardiovascular and digestive benefits (IFIC, 2018; Bimbo et al., 2017; Siró et al., 2008). Our market analysis shows that milk and dairy is covering all of these top desired health benefits. In comparison to Year 1, curiosity becomes the most important reason why consumers buy FF (33.2 \% vs $28.3 \%$ ) (Table 2). Curiosity indicates consumer's desire to try new products, to routinely vary the choice of food products available on the market and are attracted by new food products (Kaushik and Rahman, 2014; Olsen et al., 2016). 
Curiosity was found to be the main motive behind younger "label users" reason to read nutrition label (Ranilović and Colić Barić, 2011). In Year 1, the majority of consumers were of opinion that our market lacks FF (59.3\%) and even $94.9 \%$ said they would buy a new FF on the market (Banjari and Petrović, 2012).

Probiotics and dairy are among the foods consumers consider as the heathiest, along with fiber, whole grains, plant protein sources and omega-3 fatty acids (IFIC, 2019). Women are more likely to buy dairy products with reduced fat content in comparison to men, underlying care for weight as the main reason (Bimbo et al., 2017; IFIC, 2018). Women are also more likely to try yoghurt with dietary fibres or calcium and prefer yoghurt as probiotic carrier (in comparison to encapsulated or added to ice cream). Generally, women have higher preference towards milk-based FF (Bimbo et al., 2017). Women in general, especially those with small children, highly educated and higher income, between
35 and 55 years old (IFIC, 2018), living in urban areas (Prodanović and Lazović, 2015) are typical FF consumers. However, purchase decision is driven by familiarity with the ingredient, brand trust and price (IFIC, 2018; IFIC, 2019; Annunziata and Vecchio, 2011).

\section{Logistic regression analysis}

In order to determine which indicators independently influence consumers' purchase decision towards FF during a span of eight years, we tested selected variables (literature-identified important drivers behind consumers' purchase behaviour) with logistic regression. Consumer's age and self-care for health were found to independently influence the decision to buy a FF (Table 3). Younger people are more likely to buy FF (likelihood dropping by $1.6 \%$ per year of age) while self-care for health increases the likelihood to buy FF by $50.2 \%$.

TABLE 3. Cross-sectional analysis of indicators correlated with consumers' purchase decision to buy a functional over a regular product, both survey years and for each year separately (multivariate logistic regression)

\begin{tabular}{l|l|l|l|l}
\hline \multicolumn{7}{l}{ Both survey years } \\
\hline Variable & Category & OR & $95 \% \mathrm{Cl}$ & $\mathrm{P}$ \\
\hline Consumer's age & Per year & 0.984 & $0.969-0.999$ & $0.034^{*}$ \\
\hline Self-care for health & $0=$ no; 2=yes & 1.502 & $1.196-1.885$ & $0.0001^{*}$ \\
\hline Constant & & 1.083 & & 0.809 \\
\hline
\end{tabular}

Survey year 2011/12

\begin{tabular}{l|l|l|l|l}
\hline Variable & Category & OR & $95 \% \mathrm{Cl}$ & $\mathbf{P}$ \\
\hline Consumer's age & Per year & 0.968 & $0.944-0.992$ & $0.011^{*}$ \\
\hline Self-care for health & 0=no; $2=y e s$ & 1.360 & $0.994-1.861$ & 0.055 \\
\hline Pre-existence of a medical condition & 0=no; 1=yes & 0.756 & $0.403-1.419$ & 0.383 \\
\hline Constant & & 3.934 & & 0.010 \\
\hline
\end{tabular}

Survey year 2019

\begin{tabular}{l|l|l|l}
\hline Variable & Category & OR & 95\% Cl \\
\hline Residence & 1 =urban; $2=$ rural & 0.419 & $0.186-0.944$ \\
\hline Self-care for health & $0=$ no; $2=y e s$ & 1.775 & $1.190-2.646$ \\
\hline Pre-existence of a medical condition & $0=$ no; $2=y e s$ & 2.316 & $1.283-4.181$ \\
\hline Constant & & 0.645 & $0.005^{*}$ \\
\hline
\end{tabular}

*significant at p<0.05; OR = Odds Ratio; $\mathrm{Cl}=$ Confidence Interval 
TABLE 4. Expectations and purchase of a particular functional dairy products among consumers who are buying functional products, for both survey years (univariate logistic regression)

\begin{tabular}{|c|c|c|c|c|}
\hline Variable & Category & OR & $95 \% \mathrm{Cl}$ & $\mathrm{P}$ \\
\hline $\begin{array}{l}\text { Have you noticed any } \\
\text { improvement? }\end{array}$ & $\begin{array}{l}1=y e s ; 2=n o ; 3=\text { didn't expect improvement; } \\
4=a m \text { not familiar with these products }\end{array}$ & 0.580 & $\begin{array}{l}0.489- \\
0.688\end{array}$ & $0.0001^{*}$ \\
\hline Expectations & $\begin{array}{l}1=\text { none; } 2 \text { =general improvement; } \\
3 \text { =health-related improvement; } 4=\text { other }\end{array}$ & 2.389 & $\begin{array}{l}1.773- \\
3.140\end{array}$ & $0.0001^{*}$ \\
\hline Buying/ consuming probiotics & $1=$ no; 2 =yes & 1.363 & $\begin{array}{l}1.234- \\
1.507\end{array}$ & $0.0001^{*}$ \\
\hline $\begin{array}{l}\text { Buying/consuming lactose-free } \\
\text { products }\end{array}$ & $1=$ no; 2 =yes & 1.334 & $\begin{array}{l}1.152- \\
1.545\end{array}$ & $0.0001^{*}$ \\
\hline $\begin{array}{l}\text { Buying/consuming products with } \\
\text { reduced fat content }\end{array}$ & $1=$ no; 2 =yes & 1.141 & $\begin{array}{l}1.043- \\
1.248\end{array}$ & $0.004^{*}$ \\
\hline $\begin{array}{l}\text { Buying/consuming yoghurt with } \\
\text { muesli }\end{array}$ & $1=$ no; 2 =yes & 1.160 & $\begin{array}{l}1.068- \\
1.261\end{array}$ & $0.0001^{*}$ \\
\hline
\end{tabular}

*significant at $\mathrm{p}<0.05 ; \mathrm{OR}=$ Odds Ratio; $\mathrm{Cl}=$ Confidence Interval

Gender, BMI or price were not found to be important drivers behind consumers' purchase decision towards FF. For example, in Year 1, product's price was important for $76.3 \%$ of respondents (Banjari and Petrović, 2012). The only constant driver across time is the self-care for health (Table 4). Residence was found to independently influence consumer's purchase decision in Year 2, ie. people living in urban areas are $58.1 \%$ more likely to buy FF in comparison to those living in rural areas (Table 4). Interestingly, in comparison to Year 1, pre-existence of a medical condition independently influences FF purchase by $31.6 \%$ (Table 4). A consumer with a medical condition is $47.4 \%$ more likely to buy a lactose-free product (OR=1.474; $95 \%$ $\mathrm{Cl} 1.211-1.794$; $\mathrm{P}<0.0001)$, regardless of what the medical condition is.

In general, people who are buying FF are more likely to buy all observed categories of functional dairy (probiotics, lactose-free and products with reduced fat content as well as yoghurt with cereals) (Table 4). These people also have high expectations regarding improvement of their well-being (35.9\% of them expects either general or health-related improvement) and, as expected, they are more likely to notice the improvement (42.0\% more likely) (Table 4).

\section{Limitations of the study}

Even though the presented findings represent valuable starting point for all future research focused on Croatia's market of functional products, we are aware they are limited. Firstly, more respondents, especially in higher age groups are needed to enable detailed analysis between age-span. Our results regarding the role of consumer's age might be biased for that reason. For that, social networks should not be the only source of information about the survey. The presented findings should not be observed from the gender-side because of the small share of male respondents. In addition, the survey should be done more often to better capture how consumers' response to the constant-changing market of functional foods. Yet, given the lack of similar research for Croatia, the discussion may not be fully representative of Croatia's circumstances. The market of functional foods, especially functional dairy products is very dynamic, growing steadily, therefore a continuous, systematic update of the database we created is needed, ideally every three to five years. Though small, the database we created contains valuable information, which can be used for the benefit of all parties involved; from manufacturers, consumers to research community. 


\section{Conclusions}

Croatia's functional dairy market showed to be highly adaptable and rapidly responsive to meet with consumers' needs and desires. Within eight years, two new growing categories of functional dairy were identified; yoghurt with chia seeds and high-protein products, while the range of lactose-free products bloomed.

Our cross-sectional study showed that the only consistent independent indicator of consumer's decision to buy a functional over a regular product is self-care for health. People who are buying FF are more likely to buy all observed categories of functional dairy, have high expectations regarding improvement of their well-being and are more likely to notice the improvement.

Unlike eight years ago, pre-existence of a medical condition was found to independently influence FF purchase, and these people are more likely to buy a lactose-free product, regardless of what the medical condition is.
Consumer's awareness improved over time, especially regarding probiotics. They are more likely to attribute a particular health-effect to a functional product, rather than generally describing them as "good for health", but also more people associate functional foods with organic products. These results imply the need for manufacturers to strengthen and better target communication strategies, for not only the new products but the existing ones as well.

\section{Acknowledgements}

The results from the first study were presented as a poster on the $3^{\text {rd }}$ Student Congress "Nutrition and Clinical Dietotherapy" in Rijeka, Croatia (25-27 May, 2012) and received the best poster award (Banjari, I., Petrović, I. (2012): Recognition of functional foods among consumers. The $3^{\text {rd }}$ Student Congress "Nutrition and Clinical Dietotherapy" Book of abstracts.).

\section{Stavovi potrošača prema tržištu funkcionalnih mliječnih proizvoda u Hrvatskoj - presječna studija}

\section{Sažetak}

Današnji potrošači od hrane žele više od tradicionalnog zadovoljenja nutritivnih potreba. Upravo je to osnovna definicija funkcionalne hrane, no mnogi su potrošači zbunjeni oko toga što funckionalnost proizvoda predstavlja. Mlijeko i mliječni proizvodi ističu se kao najveći segment funkcionalnih proizvoda, a tržište funkcionalnih mliječnih proizvoda u Hrvatskoj je veoma raznoliko. Cilj je bio napraviti analizu tržišta funkcionalnih mliječnih proizvoda u Hrvatskoj te ispitati jesu li se stavovi potrošača prema funkcionalnim proizvodima općenito i funkcionalnim mliječnim proizvodima promijenili u periodu od osam godina (usporedbom 2011/12. i 2019. godine). Analiza tržišta napravljena je prema standardiziranoj metodologiji, dok su stavovi potrošača ispitani online anketom kreiranom specifično za potrebe istraživanja. Ista anketa je korištena u oba navrata. Ukupno je 231 ispitanik ispunio anketu 2011./12. godine a 221 2019. godine. U usporedbi sa 2011./12. godinom, statistički značajno manje ispitanika je izjavilo kako kupuju funkcionalnu hranu (44,3 \% 2019. vs 63,5 \% 2011./12., p=0,026) no svijest potrošača se povećala, posebice u pogledu probiotičkih mliječnih proizvoda. U periodu od osam godina identificirane su dvije nove kategorije funkcionalnih mliječnih proizvoda: jogurt s chia sjemenkama i proizvodi s povećanim udjelom proteina, uz značajno proširenu paletu proizvoda bez laktoze. Presječna analiza pokazala je kako je jedini konstantan neovisni čimbenik koji će utjecati na odluku potrošača da kupi funkcionalni proizvod briga za vlastito zdravlje, koje povećava vjerojatnost za kupovinu za 50,2 \%. $\cup$ periodu od osam godina, postojanje zdravstvenog problema povećava vjerojatnost kupovine proizvoda bez laktoze (za 47,4\%), neovisno o kojem zdravstvenom problemu se radi. Unatoč utvrđenim 
pozitivnim pomacima, opća svijest potrošača o tome što odlikuje funkcionalnost proizvoda i koja je njihova namjena su manjkavi. Naši rezultati govore u prilog potrebi za jačom, specifično usmjerenom strategijom informiranja potrošača od strane proizvođača temeljenoj na znanstvenim činjenicama.

\section{Ključne riječi: funkcionalni mliječni proizvodi, analiza tržišta, stavovi potrošača, svijest potrošača, zdravstveni učinci}

\section{References}

1. Akalamkam, K., Mitra, J.K. (2017): Consumer Pre-purchase Search in Online Shopping: Role of Offline and Online Information Sources. Business Perspectives and Research 6 (1), 42-60 https://doi.org/10.1177/2278533717730448

2. Annunziata, A., Vecchio, R. (2011): Functional foods development in the European market: A consumer perspective. Journal of Functional Foods 3 (3), 223-228. https://doi.org/10.1016/j.jff.2011.03.011

3. Banjari, I., Petrović, I. (2012): Recognition of functional foods among consumers (in Croatian, Abstract only). "Book of Abstracts - $3^{\text {rd }}$ Student Congress Nutrition and Clinical Dietotherapy" with international participation, Rijeka, Croatia, March 25-27, pp. 50-51.

4. Bimbo, F., Bonnano, A., Nocella, G., Viscecchia, R., Nardone, G., De Devitiis, B., Carlucci, D. (2017): Consumers' acceptance and preferences for nutrition - modified and functional dairy products: a systematic review. Appetite 113, 141-154. https://doi.org/10.1016/j.appet.2017.02.031

5. CBS, Croatian Bureau of Statistics (2019): Basic Characteristcs of Household Consumption in 2017. No. 14.1.2., CBS, Zagreb.

6. CBS, Croatian Bureau of Statistics (2016): Statistical information 2016. CBS, Zagreb.

7. CBS, Croatian Bureau of Statistics (2011): Household Budget Survey in 2009. CBS, Zagreb.

8. CBS, Croatian Bureau of Statistics (2012): Household Budget Survey in 2010. CBS, Zagreb.

9. Čalić, S., Friganović, E., Maleš, V., Mustapić, A. (2011): Funkcionalna hrana i potrošači. Praktični menadžment 2 (1), 51-57.

10. Domiter, M. (2019): Potrošači i funkcionalna hrana u Hrvatskoj - tržište funkcionalnih mliječnih proizvoda. Diplomski rad, Sveučilište Josipa JurjaStrossmayera u Osijeku, Prehrambeno-tehnološki fakultet Osijek.

11. Dowling, C. (2016): Social media strategy for your food business. https://www.tasteofscience.com/articles/648/ social-media-strategy-for-your-food-business.html [20.9.2019.]
12. Dunford, E., Webster, J., Metzler, A.B., Czernichow, S., Ni Mhurchu, C., Wolmarans, P., Snowdon, W., L'Abbe, M., Li, N., Maulik, P.K., Barquera, S., Schoj, V., Allemandi, L., Samman, N., de Menezes, E.W., Hassell, T., Ortiz, J., Salazar de Ariza, J., Rahman, A.R., de Núñez, L., Garcia, M.R., van Rossum, C., Westenbrink, S., Thiam, L.M., MacGregor, G., Neal, B.; Food Monitoring Group. (2012): International collaborative project to compare and monitor the nutritional composition of processed foods. European Journal of Preventive Cardiology 19 (6), 1326-1332. https://doi.org/10.1177/1741826711425777

13. EC, European Commission: Nutrition and Health Claims, 2006. https://ec.europa.eu/food/safety/labelling_nutrition/ claims_en [08.02.2020.]

14. FDF, Food and Drink Federation (2015): Guidance on "FreeFrom" Allergen claims. https://www.fdf.org.uk/corporate_ pubs/brc-free-from-guidance.pdf [06.02.2020.]

15. Goetzke, B., Nitzko, S., Spiller, A. (2014): Consumption of organic and functional food. A matter of well-being and health? Appetite 77, 96-105. https://doi.org/10.1016/j.appet.2014.02.012

16. Granato, D., Branco, G.F., Nazzaro, F., Cruz, A.G., Faria, J.A.F. (2010): Functional foods and nondairy probiotic food development: trends, concepts, and products. Comprehensive Reviews in Food Science and Food Safety 9 (3), 292-302. https://doi.org/10.1111/j.1541-4337.2010.00110.x

17. Hosni, H., Periklis, D., Baourakis, G. (2017): Consumers Attitude Towards Healthy Food: "Organic and Functional Foods". International Journal of Food and Beverage Manufacturing and Business Models 2 (2), 15. https://doi.org/10.4018/ijfbmbm.2017070105

18. Huynen, M.M., Martens, P., Hilderink, H.B. (2005): The health impacts of globalisation: a conceptual framework. Global Health 1, 14. https://doi.org/10.1186/1744-8603-1-14

19. IEEP, Institute for European Environmental Policy (2019): A vision for the future of the European dairy industry. IEEP, Brussels/London.

20. IFIC, International Food Information Council Foundation (2019): 2019 Food \& Health Survey. IFIC.

21. IFIC, International Food Information Council Foundation (2018): 2018 Food \& Health Survey. IFIC.

22. IPA Europe, International Probiotics association (2020): Market. http://www.ipaeurope.org/market.php [05.02.2020.] 
23. Jasiulewicz, A., Lemanowicz, M. (2016): Motives and barriers to the consumption of innovative food products by Polish and Ukrainian consumers. Review of Innovation and Competitiveness: A Journal of Economic and Social Research 2 (4), 57-70. https://doi.org/10.32728/ric.2016.24/4

24. Kapsak, W.R., Rahavi, E.B., Childs, N.M., White, C. (2011): Functional foods: Consumer attitudes, perceptions, and behaviors in a growing market. Journal of the American Dietetic Association 111 (6), 804-810. https://doi.org/10.1016/j.jada.2011.04.003

25. Kaushik, A.K., Rahman, Z. (2014): Perspectives and dimensions of consumer innovativeness: A literature review and future agenda. Journal of International Consumer Marketing 26 (3), 239-263. https://doi.org/10.1080/08961530.2014.893150

26. Kolarić Kravar, S. (2017): Nutritivna deklaracija kao obvezni podatak na hrani. https://www.hah.hr/wpcontent/uploads/2017/03/4_Nutritivna-deklaracija.pdf [06.02.2020.]

27. Landström, E., Hursti, U.K., Becker, W., Magnusson, M. (2007): Use of functional foods among Swedish consumers is related to health-consciousness and perceived effect. British Journal of Nutrition 98 (5): 10581069.

https://doi.org/10.1017/S0007114507761780

28. Martins, N., Oliveira, M.B.P.P., Ferreira, I.C.F.R. (2018): Development of Functional Dairy Foods. In: Mérillon, J.M., Ramawat K. (eds) Bioactive Molecules in Food, Springer, Cham, pp. 1-19.

29. Muminović, S., Pavlović, V. (2012): Profitability of Dairy Industry in Slovenia, Croatia and Serbia. Mljekarstvo 62 (2), 96-110.

30. MZSS, Ministry of Health and Social Welfare (2008): Pravilnik o hrani obogaćenoj nutrijentima (dodavanje vitamina, mineral i drugih tvari hrani) (ENG: Regulation of nutrient-enriched foods (addition of vitamins, minerals and other substances to foods)). Narodne novine 148/08.

31. Olsen, S.O., Tudoran, A.A., Honkanen, P., Verplanken, B. (2016): Differences and Similarities between Impulse Buying and Variety Seeking: A personality-based perspective. Psychology \& Marketing 33 (1), 36-47. https://doi.org/10.1002/mar.20853

32. Ozen, A.E., Pons, A., Tur, J.A. (2012): Worldwide consumption of functional foods: a systematic review. Nutrition Reviews 70 (8), 472-481. https://doi.org/10.1111/j.1753-4887.2012.00492.x

33. Phillipov, M. (2016): Using media to promote artisan food and beverages: insights from the television industry. British Food Journal 118 (3), 588-602. https://doi.org/10.1108/BFJ-06-2015-0219

34. Prodanović, R., Lazović, K. (2015): Percepcija i profil potrošača funkcionalne hrane. Ekonomija: teorija i praksa VIII (4), 65-85.

35. Ranilović, J., Colić Barić, I. (2013): Perceived barriers and motives to reading nutrition label among label 'nonusers' in Croatia. Croatian Journal of Food Technology, Biotechnology and Nutrition 8 (1-2), 52-57.
36. Ranilović, J., Colić Barić, I. (2011): Differences between younger and older populations in nutrition label reading habits. British Food Journal 113 (1), 109-121. https://doi.org/10.1108/00070701111097376

37. Roberfroid, M.B. (2000): Concepts and strategy of functional food science: the European perspective. The American Journal of Clinical Nutrition 71, 1660S-1664S. https://doi.org/10.1093/ajcn/71.6.1660S

38. Shiby, V.K., Mishra, H.N. (2013): Fermented milks and milk products as functional foods - A review. Critical Reviews in Food Science and Nutrition 53 (5), 482-496. https://doi.org/10.1080/10408398.2010.547398

39. Siró, I., Kápolna, E., Kápolna, B., Lugasi, A. (2008): Functional food. Product development, marketing and consumer acceptance: a review. Appetite 51 (3), 456-467. https://doi.org/10.1016/j.appet.2008.05.06

40. Southey, F. (2019): Social media influencers unfit for weight management advice: 'Misinformation can undermine public health campaigns'. Nutraingredients.com. William Reed Business Media Ltd, Published: April 30.

41. Statista (2020a): Revenue generated by the functional food market worldwide from 2019 to 2025. https://www. statista.com/statistics/252803/global-functional-foodsales/ [05.02.2020.]

42. Statista (2020b): Adult prevalence of gastrointestinal conditions by country 2019. https://www.statista.com/ statistics/418515/adult-prevalence-of-gastrointestinalconditions-by-country/ [05.02.2020.]

43. Temesi, A., Bacsó, Á., Grunert, K.G., Lakner, Z. (2019): Perceived correspondence of health effects as a new determinant influencing purchase intention for functional food. Nutrients 11 (4), 740. https://doi.org/10.3390/nu11040740

44. Transparency Market Research (2016): Global Probiotics Market - Launch of New Functional Food Products Supports Positive Growth; market to hit US $\$ 96$ billion by 2020. https://www.globenewswire.com/ news-release/2016/07/28/859580/0/en/GlobalProbiotics-Market-Launch-of-New-Functional-FoodProducts-Supports-Positive-Growth-market-to-hit-US-96billion-by-2020-TMR.html [06.02.2020.]

45. Vergari, F., Tibuzzi, A., Basile, G. (2010): An overview of the functional food market: From marketing issues and commercial players to future demand from life in space. In: Giardi, M.T., Rea, G., Berra, B. (eds). Bio-Farms for Nutraceuticals. Advances in Experimental Medicine and Biology, Springer US.

46. Viola, G.C.V., Bianchi, F., Croce, E., Ceretti, E. (2016): Are food labels effective as a means of health prevention? Journal of Public Health Research 5 (3), 768. https://doi.org/10.4081/jphr.2016.768

47. WHO, World Health Organization (2006): BMI classification. http://apps.who.int/bmi/index. jsp?introPage=intro_3.html [25.07.2019.] 